\title{
Treatment of Dyrk1A-dependent Mental Retardation of Down Syndrome: Isolation of Human Dyrk1A-specific shRNA
}

\author{
Min-Su Jung, Yeun-Soo Kim, Juhyun Kim', Joung-Hun Kim', Sul-Hee Chung and Woo-Joo Song* \\ Institute for Brain Science and Technology (IBST), Graduate Program in Neuroscience, Inje University, Busan, 614-735, Korea \\ ${ }^{1}$ Department of Life Science, Pohang University of Science and Technology, Pohang, Kyungbuk, 790-784, Korea
}

Received December 4, 2008 / Accepted March 3, 2009

\begin{abstract}
Down syndrome (DS) results from overexpressed genes on an extra copy of human chromosome 21. Among various phenotypes seen in DS patients, mental retardation, such as learning and memory deficits, is a major factor that prevents DS individuals from leading fully independent lives. The Dyrk1A gene that plays a critical role in neurodevelopment has been isolated from chromosome 21, and transgenic mice with over-expression of Dyrk1A show severe hippocampal dependent learning and memory defects. In the present study, as an initial step to test the treatment of Dyrk1A dependent mental retardation phenotypes in model animals, we isolated human Dyrk1A specific lentiviral short hairpin RNA (shRNA) that inhibits the exogenous human Dyrk1A expression, but not the endogenous mouse expression in transgenic mice with human Dyrk1A overexpression. This limited and specific repression of exogenous human Dyrk1A will prove to be valuable information, if Dyrk1A dependent learning and memory defects in DS patients could be treated or at least ameliorated in vivo.
\end{abstract}

Key words : Down syndrome, Dyrk1A, mental retardation, RNA interference, lentivirus

\section{Introduction}

With a frequency of one in roughly every 800 births, Down syndrome (DS) is the most common genetic anomaly and results from the presence of an extra copy of human chromosome 21 [9,12]. In addition to characteristic physical features, individuals with DS show a variety of phenotypes, such as low muscle tone, congenital heart defects, immune defects, a high incidence of leukemia, and early onset of Alzheimer-like dementia $[11,14,15]$. DS patients also suffer from mental retardation, which is a major factor preventing them from leading fully independent lives in their early to middle-age years. As a result of the search for the responsible gene(s), the Dyrk1A gene, which plays a critical role in neurodevelopment, was isolated from chromosome 21 $[5,10,19,21]$. Dyrk1A is a member of the Dyrk [dual-specificity Tyrosine(Y) regulated kinase] family, and has dual substrate specificities: tyrosine-321 residue autophosphorylation for self-activation and serine/threonine kinase [10,13]. Transgenic (Tg) mice overexpressing human or mouse Dyrk1A show learning and memory defects [1,2,20]. Previously, the authors of this study reported the production of transgenic mice, Dyrk1A BAC Tg, using a bacterial artifi-

*Corresponding author

Tel : +82-51-892-4186, Fax : +82-51-892-0059

E-mail : wjsong@inje.ac.kr cial chromosome (BAC) clone that contained the complete human Dyrk1A genome including the endogenous promoter [1]. These Dyrk1A BAC Tg mice overexpressed human Dyrk1A and showed severe learning and memory deficiencies, indicating that Dyrk1A is strongly associated with the mental retardation seen in DS. At present, no therapy is available to treat the mental retardation associated with DS.

In 1995, during attempts to repress a specific gene expression using antisense RNA in the maternal germ line, RNA interference (RNAi) was unexpectedly discovered [3,6]. RNAi refers to the sequence-specific target cellular or viral RNA degradation process $[16,18]$. This phenomenon has been observed in a wide variety of organisms, including plants, worms, flies, and vertebrates, and has emerged as a powerful technique for studying the function of proteins and in treating various diseases $[4,7,22]$. For gene therapy purposes, the lentiviral system is considered the suitable RNAi delivery method, since lentivirus has proved useful for efficient transduction into various cells as well as for long-term expression and for infection into non-dividing cells.

In this study, a recombinant lentivirus expressing a human Dyrk1A-specific short hairpin RNA (shRNA) is isolated to be used in testing potential treatment of learning and memory deficiencies observed in human Dyrk1A overexpressing transgenic mice. The human Dyrk1A specific 
shRNA will specifically repress the exogenous human Dyrk1A of transgenic mice overexpressing human Dyrk1A while the endogenous mouse Dyrk1A is normally expressed. This viral shRNA could be a valuable resource in testing the potential for reversal of learning and memory deficiencies seen in Dyrk1A transgenic mice and DS patients.

\section{Materials and Methods}

\section{Plasmid constructs}

Mouse 763 amino acid full-length Dyrk1A cDNA was cloned into the mammalian expression vector pcDNA3.1 as previously described [21]. The human 754 amino acid Dyrk1A cDNA in pcDNA3.1 was kindly provided by Dr. de la Luna. siRNAs that specifically inhibit the expression of human Dyrk1A were cloned into pLentiLox3.7 virus vector for viral production [17]. The construction of the recombinant vector was executed as follows: the sense sequence consisted of the selected siRNA sequence followed by a TTCAAGAGA loop, the reverse complementary sequence, and 6 Thymidines with restriction sites of $\mathrm{HpaI}$ and XhoI at $5^{\prime}$ and $3^{\prime}$, respectively. The sense and complementary antisense oligos were synthesized and annealed for cloning into the HpaI and XhoI sites of the pLentiLox3.7 vector.

\section{siRNA transfection and Western analysis}

Sixty pmole of synthesized duplex siRNA with TT overhang was cotransfected with human or mouse Dyrk1A clone into human embryonic kidney (HEK293T) cells in 6-well plates (seeded at a density of $7 \times 10^{5}$ cells/well one day earlier) using Lipofectamine 2000. FITC conjugated GFP specific siRNA was used as a transfection control. One day after siRNA treatment, cells were lysed in RIPA buffer. The protein concentration was measured using the BCA method (Sigma) and cell lysates were used for Western analysis. The anti-Dyrk1A antibody was custom-made as previously described [1].

\section{Viral production and transduction}

A three-plasmid system was used to produce the human Dyrk1A-specific shRNA expressing lentivirus. The system consists of the packaging, envelope and shRNA-expressing vector, and allows the production of a self-replication-incompetent virus for safe manipulation. One day before transfection, HEK293T cells were seeded at a density of $3 \times 10^{6}$ cells $/ 100 \mathrm{~mm}$ dish. The following day, all $12 \mu \mathrm{g}$ of the three plasmids were transfected. After $48 \sim 72 \mathrm{hr}$, the viral supernatant was collected for infection.

To accomplish the viral infection, HEK293T cells were seeded on one day, and the following day the cells were infected with virus. Six hr later the medium was changed and cells were further incubated for $24 \mathrm{hr}$. The next day, the human or mouse Dyrk1A clone was transfected as previously described. $36 \sim 48 \mathrm{hr}$ after transfection, cells were harvested and the cell lysates were prepared for Western analysis.

\section{Results}

\section{Selection of human Dyrk1A-specific siRNA}

Several small interfering RNA (siRNA) design programs including siRNA wizard were used to select the candidate siRNAs, which consisted of 18 25 nucleotide long human Dyrk1A. The sequence was then compared with the mouse Dyrk1A sequence (93\% identity at the nucleotide level), and 10 human Dyrk1A siRNAs with 2 5 nucleotides different from those of the mouse sequence (Table 1) were selected. Each synthesized siRNA was cotransfected with the mouse or human Dyrk1A clone into HEK293T. One day after transfection, cell lysates were subjected to Western analysis to determine whether each siRNA inhibits the expression of human and/or mouse Dyrk1A. Fig. 1 shows representative blots of screening for human-specific siRNA isolations. siRNAs \#1 and \#2 showed a very strong and a moderate inhibition on the human Dyrk1A expression, respectively, while siRNA \#3 showed a minimal repression for the human Dyrk1A expression. None of the three siRNAs (\#1, \#2 or

Table 1. DNA sequences of selected 10 human Dyrk1A siRNAs

\begin{tabular}{|c|c|c|}
\hline siRNA & Sequence $^{1}$ & \\
\hline$\# 1$ & 5-TCTATGACTTGCTGAGAAA-3 & $(2)$ \\
\hline$\# 2$ & 5-GTTCGGCTTGCACCGTCATTI-3 & (3) \\
\hline \#3 & 5-GTTTCTGCCTTATCATATTCT-3 & (2) \\
\hline$\# 4$ & 5-GTACATTCGTCAAAGCTCAGGT-3 & (4) \\
\hline$\# 5$ & 5-GCCAGCCAAAACATAAGTGACC-3 & (2) \\
\hline \#6 & 5-GGAGACGATTCIAGTCATAAG-3 & $(2)$ \\
\hline$\# 7$ & 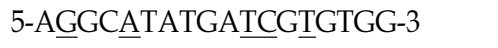 & (5) \\
\hline$\# 8$ & 5-GAGTCAAGGTCATACGGTCGGCT-3 & (4) \\
\hline$\# 9$ & 5-AACA AGGTTTCTGCCTTATCAT-3 & (3) \\
\hline$\# 10$ & 5-GATㅅGTTGACTTTTGGCAGT-3 & (3) \\
\hline
\end{tabular}

${ }^{1}$ The mismatched human Dyrk1A nucleotide sequences different from the mouse sequences are underlined, and number of mismatch is shown in parenthesis. 
A

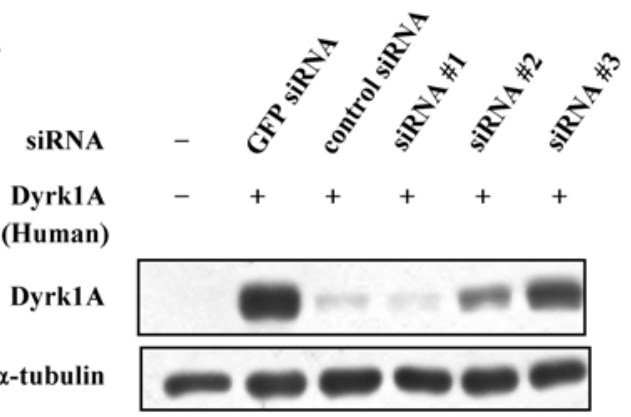

B

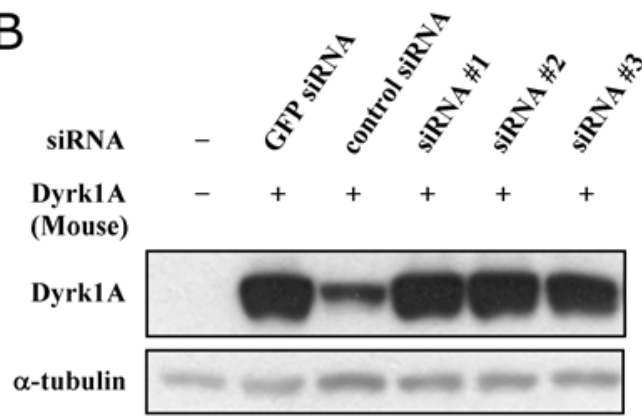

Fig. 1. Screening of siRNAs. The indicated siRNA was cotransfected with human (A) or mouse (B) Dyrk1A-expressing plasmid into HEK293T cells. Cell lysate $(50 \mu \mathrm{g})$ was subjected to Western blotting to analyze the Dyrk1A repression. Non-specific GFP siRNA was used as a transfection negative control and a control siRNA with a common sequence for both human and mouse Dyrk1A was used a positive control.

\#3) inhibited the expression of the mouse Dyrk1A. From 10 siRNAs tested, siRNAs \#1 and \#9 were identified as having specific inhibitory activity on the expression of human Dyrk1A, but not on mouse Dyrk1A (Fig. 2). These two siRNA sequences were used for the construction of recombinant viral vectors that express shRNA to test the human Dyrk1A-specific inhibition.

\begin{tabular}{|c|c|c|c|c|c|c|}
\hline \multirow[b]{2}{*}{ Dyrk1A } & \multicolumn{3}{|c|}{ Human } & \multicolumn{3}{|c|}{ Mouse } \\
\hline & + & + & + & + & + & + \\
\hline GFP siRNA & + & - & - & + & - & - \\
\hline siRNA \#1 & - & + & - & - & + & - \\
\hline SiRNA \#9 & - & - & + & - & - & + \\
\hline Dyrk1A & & & & & & \\
\hline$\alpha$-tubulin & & & & & & \\
\hline
\end{tabular}

Fig. 2. Isolation of human Dyrk1A-specific siRNAs \#1 and \#9. The cell lysates treated with the indicated siRNA, and mouse or human Dyrk1A-expressing plasmids were subjected to Western blotting to measure the Dyrk1A repression.

\section{shRNA lentivirus production}

For long-term exogenous human Dyrk1A gene repression and for infection into non-dividing neuronal cells of Dyrk1A BAC Tg mice, two siRNAs (\#1 and \#9) with specific repression activity for human Dyrk1A expression were cloned into lentiviral vectors for virus production expressing shRNA. Expression of Green Fluorescent Protein (GFP) under the control of a CMV promoter was used as an indication of shRNA expression. A three-vector system was used to produce the recombinant lentivirus. The recombinant pLentiLox3.7 clone was cotransfected with the plasmid expressing gag and pol genes into HEK293T cells for viral production. The production of virus was estimated by observing the intensity of the GFP signal under a fluorescent microscope (Fig. 3). A virus titer of $10^{6} \sim 10^{7} \mathrm{cfu} / \mathrm{ml}$ was used for infection.

Isolation of the human-specific shRNA expressing lentivirus

The following procedures were taken to check the repression of Dyrk1A expression by viral infection. To allow sufficient time for viral shRNA expression, HEK293T cells were first treated with virus. Then next day, the infected cells were transiently transfected with the human or mouse Dyrk1A for exogenous expression. The following day, a good expression of GFP was routinely observed, indicating good infection and expression of shRNA. The cell lysates were tested for Dyrk1A expression. As expected from the siRNA treatment, neither treatment with viral shRNA \#1 nor treatment with viral shRNA \#9 inhibited the expression of mouse Dyrk1A. Treatment with shRNA \#9 was found to strongly repress the expression of human Dyrk1A, while shRNA \#1 had a little effect (Fig. 4). In conclusion, a human
A

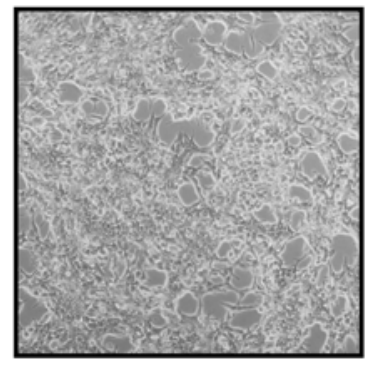

B

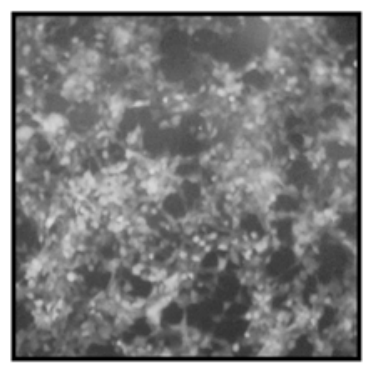

Fig. 3. Lentivirus production. Optical (A) and GFP fluorescent (B) microscopic images of HEK293T cells transfected with three plasmids, recombinant pLentiLox3.7, VSVg and $\Delta 8.9$. 


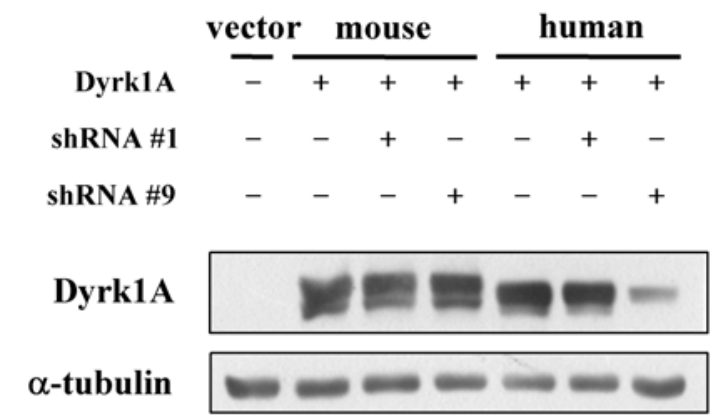

Fig. 4. Isolation of recombinant lentivirus expressing humanspecific shRNA. HEK293T cells infected with lentivirus expressing shRNA \#1 or \#9, and transfected with mouse or human Dyrk1A-expressing plasmid were lysed for the analysis of Dyrk1A repression.

Dyrk1A-specific shRNA expressing lentivirus required for in vivo study in evaluating the treatment of mental retardation of Dyrk1A BAC Tg mice was isolated in this study.

\section{Discussion}

DS is caused by the duplication of human chromosome 21. Since the genome size of chromosome 21 is larger than $33 \mathrm{Mb}$ and the genome contains about 300 genes [8], it is overwhelming to pinpoint the individual genes responsible for each phenotype of DS, and it is an even more daunting task to try to treat those phenotypes. Among the many phenotypes of DS, mental retardation is the most devastating impediment to patients with DS being able to lead independent lives. Thus far, there is no therapeutic drug available for the treatment of the mental retardation associated with DS. In 1996, several research teams reported the isolation of the Dyrk1A gene $[5,10,19,21]$, and produced Dyrk1A transgenic mice with learning and memory defects, opening a door for a potential therapeutic approach $[1,2,20]$. Dyrk1A BAC Tg mice produced in the laboratory of this study carry one extra copy of the human Dyrk1A genome in addition to the endogenous two mouse Dyrk1A copies, and showed severe learning and memory deficits. Such mice provide a unique tool for testing whether the specific repression of extra human Dyrk1A could reverse the mental retardation seen in this model animal. As an initial step toward conducting such testing, this study reports the isolation of a human specific Dyrk1A shRNA lentivirus that specifically inhibits the exogenous human Dyrk1A expression, but not the endogenous mouse one. Successful targeting of the isolated shRNA into affected brain areas, such as the hippocampus, and analysis would provide a valuable next step in developing therapeutic interventions in the future.

\section{Acknowledgments}

This work was supported by the Korea Science and Engineering Foundation (KOSEF) grant funded by the Korea government (R01-2007-000-11910-0 to W.J.S.). This work was also supported by the Korea Research Foundation Grant funded by the Korean Government (KRF-2007-331-E00031 to W.J.S. and KRF-2008-314-E00180 to W.J.S.).

\section{References}

1. Ahn, K. J., H. K. Jeong, H. S. Choi, S. R. Ryoo, Y. J. Kim, J. S. Goo, S. Y. Choi, J. S. Han, I. Ha, and W. J. Song. 2006. DYRK1A BAC transgenic mice show altered synaptic plasticity with learning and memory defects. Neurobiol. Dis. 22, 463-472.

2. Altafaj, X., M. Dierssen, C. Baamonde, E. Marti, J. Visa, J. Guimera, M. Oset, J. R. Gonzalez, J. Florez, C. Fillat, and X. Estivill. 2001. Neurodevelopmental delay, motor abnormalities and cognitive deficits in transgenic mice overexpressing Dyrk1A (minibrain), a murine model of Down's syndrome. Hum. Mol. Genet. 10, 1915-1923.

3. Fire, A., S. Xu, M. K. Montgomery, S. A. Kostas, S. E. Driver, and C. C. Mello. 1998. Potent and specific genetic interference by double-stranded RNA in Caenorhabditis elegans. Nature 391, 806-811.

4. Grishok, A., H. Tabara, and C. C. Mello. 2000. Genetic requirements for inheritance of RNAi in C. elegans. Science 287, 2494-2497.

5. Guimera, J., C. Casas, C. Pucharcos, A. Solans, A. Domenech, A. M. Planas, J. Ashley, M. Lovett, X. Estivill, and M. A. Pritchard. 1996. A human homologue of Drosophila minibrain (MNB) is expressed in the neuronal regions affected in Down syndrome and maps to the critical region. Hum. Mol. Genet. 5, 1305-1310.

6. Guo, S., and K. J. Kemphues. 1995. par-1, a gene required for establishing polarity in C. elegans embryos, encodes a putative Ser/Thr kinase that is asymmetrically distributed. Cell 81, 611-620.

7. Hamilton, A. J. and D. C. Baulcombe. 1999. A species of small antisense RNA in posttranscriptional gene silencing in plants. Science 286, 950-952.

8. Hattori, M., A. Fujiyama, T. D. Taylor, H. Watanabe, T. Yada, H. S. Park, A. Toyoda, K. Ishii, Y. Totoki, D. K. Choi, Y. Groner, E. Soeda, M. Ohki, T. Takagi, Y. Sakaki, S. Taudien, K. Blechschmidt, A. Polley, U. Menzel, J. Delabar, K. Kumpf, R. Lehmann, D. Patterson, K. Reichwald, A. Rump, M. Schillhabel, A. Schudy, W. Zimmermann, A. Rosenthal, J. Kudoh, K. Schibuya, K. Kawasaki, S. Asakawa, 
A. Shintani, T. Sasaki, K. Nagamine, S. Mitsuyama, S. E. Antonarakis, S. Minoshima, N. Shimizu, G. Nordsiek, K. Hornischer, P. Brant, M. Scharfe, O. Schon, A. Desario, J. Reichelt, G. Kauer, H. Blocker, J. Ramser, A. Beck, S. Klages, S. Hennig, L. Riesselmann, E. Dagand, T. Haaf, S. Wehrmeyer, K. Borzym, K. Gardiner, D. Nizetic, F. Francis, H. Lehrach, R. Reinhardt, and M. L. Yaspo. 2000. The DNA sequence of human chromosome 21. Nature 405, 311-319.

9. Jacobs, P. A., A. G. Baikie, W. M. Court Brown, and J. A. Strong. 1959. The somatic chromosomes in mongolism. Lancet 1, 710.

10. Kentrup, H., W. Becker, J. Heukelbach, A. Wilmes, A. Schurmann, C. Huppertz, H. Kainulainen, and H. G. Joost. 1996. Dyrk, a dual specificity protein kinase with unique structural features whose activity is dependent on tyrosine residues between subdomains VII and VIII. J. Biol. Chem. 271, 3488-3495.

11. Korenberg, J. R., X. N. Chen, R. Schipper, Z. Sun, R. Gonsky, S. Gerwehr, N. Carpenter, C. Daumer, P. Dignan, C. Disteche, and et. al. 1994. Down syndrome phenotypes: the consequences of chromosomal imbalance. Proc. Natl. Acad. Sci. USA 91, 4997-5001.

12. Lejeune, J., M. Gautier, and R. Turpin. 1959.Study of somatic chromosomes from 9 mongoloid children. C R Hebd. Seances Acad. Sci. 248, 1721-1722.

13. Lochhead, P. A., G. Sibbet, N. Morrice, and V. Cleghon. 2005. Activation-Loop Autophosphorylation Is Mediated by a Novel Transitional Intermediate Form of DYRKs. Cell 121, 925-936.

14. Patterson, D. 1987. The causes of Down syndrome. Sci. Am. 257, 52-57, 60.

15. Pulsifer, M. B. 1996. The neuropsychology of mental retardation. J. Int. Neuropsychol. Soc. 2, 159-176.
16. Rocheleau, C. E., W. D. Downs, R. Lin, C. Wittmann, Y. Bei, Y. H. Cha, M. Ali, J. R. Priess, and C. C. Mello. 1997. Wnt signaling and an APC-related gene specify endoderm in early C. elegans embryos. Cell 90, 707-716.

17. Rubinson, D. A., C. P. Dillon, A. V. Kwiatkowski, C. Sievers, L. Yang, J. Kopinja, D. L. Rooney, M. Zhang, M. M. Ihrig, M. T. McManus, F. B. Gertler, M. L. Scott, and L. Van Parijs. 2003. A lentivirus-based system to functionally silence genes in primary mammalian cells, stem cells and transgenic mice by RNA interference. Nat. Genet. 33, 401-406.

18. Sharp, P. A., and P. D. Zamore. 2000. Molecular biology. RNA interference. Science 287, 2431-2433.

19. Shindoh, N., J. Kudoh, H. Maeda, A. Yamaki, S. Minoshima, Y. Shimizu, and N. Shimizu. 1996. Cloning of a human homolog of the Drosophila minibrain/rat Dyrk gene from "the Down syndrome critical region" of chromosome 21. Biochem. Biophys. Res. Commun. 225, 92-99.

20. Smith, D. J., M. E. Stevens, S. P. Sudanagunta, R. T. Bronson, M. Makhinson, A. M. Watabe, T. J. O'Dell, J. Fung, H. U. Weier, J. F. Cheng, and E. M. Rubin. 1997. Functional screening of $2 \mathrm{Mb}$ of human chromosome 21q22.2 in transgenic mice implicates minibrain in learning defects associated with Down syndrome. Nat. Genet. 16, 28-36.

21. Song, W. J., L. R. Sternberg, C. Kasten-Sportes, M. L. Keuren, S. H. Chung, A. C. Slack, D. E. Miller, T. W. Glover, P. W. Chiang, L. Lou, and D. M. Kurnit. 1996. Isolation of human and murine homologues of the Drosophila minibrain gene: human homologue maps to 21q22.2 in the Down syndrome "critical region". Genomics 38, 331-339.

22. Tabara, H., A. Grishok, and C. C. Mello. 1998. RNAi in C. elegans: soaking in the genome sequence. Science 282, 430-431.

\section{초록 : 다운증후군의 Dyrk1A 의존적 뇌기능저하의 치료: 인간 Dyrk1A 특이적 shRNA 발굴 \\ 정민수 · 김연수 · 김주현 ${ }^{1} \cdot$ 김정훈 $^{1} \cdot$ 정설희 · 송우주* \\ (인제대학교 뇌과학기술연구소, ${ }^{1}$ 포항공과대학교 생명과학과)}

다운증후군은 추가적으로 존재하는 인간염색체 21 번에 위치한 유전자의 과발현으로 발병한다. 다운증후군 환자 에서 보이는 여러 증상들 중 학습과 기억능력 저하와 같은 뇌기능 저하는 다운증후군 환자가 독립적인 생활을 영위하는데 가장 큰 걸림돌이 된다. 인간염색체 21번에 위치하는 Dyrk1A는 신경발달에 중요한 역할을 하는 단백질 로 Dyrk1A를 과발현 하는 형질전환 생쥐에서 심각한 해마 의존적 학습과 기억 장애가 보고되었다. 본 연구에서는 인간 Dyrk1A를 과발현 하는 형질전환 생쥐와 RNA interference (RNAi) 방법을 이용하여 endogenous mouse Dyrk1A의 발현은 정상적으로 유지하면서 exogenous human Dyrk1A 발현은 특이적으로 저해함으로써 인간 Dyrk1A 과발현에 의한 학습과 기억 능력저하를 회복시킬 수 있는지 동물모델에서 검증하기 위한 첫 단계로 인간 Dyrk1A 특이적 lentiviral short hairpin RNA (shRNA)를 발굴하였다. 발굴된 shRNA를 이용한 형질전환 모델생쥐 에서의 증상의 회복 가능성 검증은 다운증후군의 뇌기능저하 치료제 개발에 중요한 정보를 제공할 것이다. 